Trusova N. V., Doctor of Economic Sciences, Professor Dmytro Motornyi Tavria State Agrotechnological University Melitopol, Zaporizhzhia region, Ukraine Chkan I. O., Candidate of Economic Sciences, Associate Professor Dmytro Motornyi Tavria State Agrotechnological University Melitopol, Zaporizhzhia region, Ukraine Chkan A. S., Candidate of Economic Sciences, Associate Professor Zaporizhzhia National University Zaporizhzhia, Ukraine

DOI: https://doi.org/10.30525/978-9934-26-064-3-16

\title{
GROCERY RETAIL IN THE STRUCTURE OF RETAIL TRADE OF UKRAINE
}

The newest and modern form of retail is «retail», the essence of which is to sell goods individually or in small batches [1]. Retail, as a specific form of retail trade, has certain characteristics and specific features in the way of selling goods and price formation with a markup of $25 \%$ to $200 \%$. The most common in today's practice are the following types of retail: grocery, network, mobile, street, nonfood retail.

Trade occupies a significant share in the economy of Ukraine. In 2019, the share of wholesale and retail trade in the overall structure of GDP was $13.2 \%$, which is $3.6 \%$ more than in 2018 [2]. Retail trade 
volumes increase annually by an average of $15-20 \%$. However, this trend has changed in 2020.

In the first half of 2020, Ukraine found itself in a new environment of restricting activities due to the pandemic and quarantine. Under these conditions, most companies have temporarily ceased operations, others have reoriented it to the format of on-line sales. This, in turn, was reflected in the performance of enterprises. In April, there was a significant decrease in sales of food and non-food products (at 43\%) compared to the level of March, which in monetary terms amounted to UAH 22780 million [3].

Despite the negative trends and conditions of activity, in general, the retail sector in Ukraine in the first half of 2020 increased by $5.9 \%$ (in comparable prices) compared to the corresponding period of 2019 [4].

The least negative impact due to quarantine restrictions was felt by grocery retailers, most of which continued their activities without significant restrictions imposed on the territory of Ukraine. In the first half of 2020, network operators increased their presence. First of all, this is due to the fact that small and micro enterprises could not «survive» the difficult conditions of doing business in quarantine. But large networks have expanded their activities.

The most active since the opening of new outlets was the trade network of ATB-Market LLC - 55 new outlets. The network of ARITEIL LLC - 46 new outlets functioned almost on a par with it. There is also a tendency to reduce the number of outlets: Vol West Retail - closed 2 stores, LLC «ECO» - 6 stores, LLC «ModernTrade» - 1 store. Despite a slight decrease in activity in the activities of the VolWest Retail network, outlets under its brands (Nash Krai, SPAR) are among the three most successful and largest retailers in Ukraine.

The success of the strategies of most leaders of grocery retail in Ukraine is confirmed by the fact that they are among the five largest retailers in Ukraine according to Forbes Ukraine [5]:

- ATB-Market LLC occupies the 2nd position, having a revenue increase of $22 \%$. The financial result of the network increased this 
year against the previous one by UAH 4.4 billion and amounted to UAH 104.9 billion;

- Fozzy Group ranks 4th in the ranking, despite the fact that there is a decrease in revenue this year by UAH 5 million. In total, the network's revenue amounted to UAH 78.2 billion.

According to Forbes Ukraine, Metro Cash \& Carry (29th position), Auchan (38th position), Varus (56th position), Novus (58th position) were also among the top 100 leaders in grocery retail in Ukraine.

In general, the effectiveness of domestic retail is carried out by the following group of factors:

- active application in practice of modern sales technologies;

- unification and standardization of technology in the network;

- automation of processes of management of activity of the enterprises as a part of retail at the expense of use of the automated information systems;

- active common advertising policy for all retail enterprises;

- launching the sale of goods under its own brand, establishing production and sales of its own line of goods;

- formation of a multi-channel communication network for communication with existing customers, attraction of new ones (format of appeal through mass media, mobile communication operators, Internet, etc.).

\section{References:}

1. What is retail? Business portal. Available at: https://copdoc.ru/articles/ 2700.html (accessed 10 March 2021).

2. Ukraine's GDP for the year decreased by 0.2\%. 112.ua. Available at: https://ua.112.ua/ekonomika/vvp-ukrainy-za-rik-skorotyvsia-na-02-529891.html (accessed 12 March 2021).

3. Retail trade statistics in Ukraine. Ministry of Finance of Ukraine. Available at: https://index.minfin.com.ua/ua/economy/trade/retail/ (accessed 12 March 2021).

4. Retail reached the level of February 2020 - an analyst at Privatbank. Business. Available at: https://business.ua/uk/rozdribna-torgivlya-vijshla-na-riven-lyutogo2020-roku-analitika-privatbanku (accessed 10 March 2021).

5. Top 15 most profitable retail chains in Ukraine according to Forbes. RAU. Available at: https://rau.ua/novyni/top-15-torgovyh-merezh-forbes/ (accessed 12 March 2021). 